\title{
Nematode-Trapping Fungi in Biological Control of Dictyocaulus viviparus
}

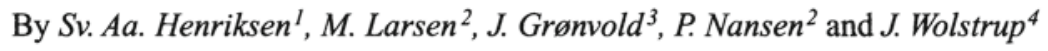 \\ ${ }^{1}$ Danish Veterinary Laboratory, Copenhagen, ${ }^{2}$ Danish Centre for Experimental Parasitology, Department of Ve- \\ terinary Microbiology, and ${ }^{3}$ Section of Zoology, and ${ }^{4}$ Section of Microbiology, Department of Ecology and Mol- \\ ecular Biology, The Royal Veterinary and Agricultural University, Frederiksberg, Denmark.
}

\begin{abstract}
Henriksen, Sv. Aa., M. Larsen, J. Grønvold, P. Nansen and J. Wolstrup: Nematodetrapping fungi in biological control of Dictyocaulus viviparus. Acta vet. scand. 1997, 38, 175-179. - Larvae of the cattle lungworm Dictyocaulus viviparus were cultured in experimental units of $200 \mathrm{~g}$ cattle faeces placed in semi-transparent trays in the laboratory. In each of 4 experimental series using this experimental unit, chlamydospores (chl) of the nematode-trapping fungus Duddingtonia flagrans were admixed to half of the faecal cultures in a concentration of $50.000 \mathrm{chl} / \mathrm{g}$. In all 4 series there was a significant reduction in the development and subsequent release of infective lungworm larvae from faecal cultures containing chlamydospores. The average reduction in larval release, caused by fungal spores, was $86 \%$.
\end{abstract}

parasites; lungworm; cattle.

\section{Introduction}

The nematode-trapping fungus Duddingtonia flagrans is able to trap migrating nematodes in three-dimensional adhesive mycelial nets (Cooke 1969). D. flagrans only produces traps when it is induced to do so, e.g. by physical contact with migrating nematodes.

In field experiments, a D. flagrans strain has been able to control free-living stages of a range of parasitic gastrointestinal nematodes of cattle, horse and pig when fungal spores were fed to the host animals (Grønvold et al. 1993, Wolstrup et al. 1994, Larsen et al. 1995, 1996, Nansen et al. 1995, 1996). But, sofar, biological control of the cattle lungworm Dictyocaulus viviparus by $D$. flagrans has not been tested neither in the laboratory nor in the field.

Earlier on, another nematode-trapping fungus, Arthrobotrys oligospora, has been tested against $D$. viviparus larvae in agar cultures in the laboratory (Nansen et al. 1988). The results showed that slow-moving nematodes, such as D. viviparus larvae, have poor trap-inducing potentials. But if traps were induced by other nematodes, D. viviparus larvae were easily trapped in the pre-formed A. oligospora nets.

The cattle lungworm D. viviparus is ovoviviparous and excretes larvae in faeces. Under normal summer temperatures in Denmark the infective third stage larvae $\left(\mathrm{L}_{3}\right)$ is reached within one to 2 weeks in the cow pats. In contrast to gastrointestinal nematodes, it has been indicated that the coprophilous fungi Pilobolus spp. may play an important role in transporting the slow-moving infective $D$. viviparus larvae from faeces to herbage from where they can be taken up by susceptible grazing calves (Jørgensen et al. 1982).

In relation to a possible biological control effect 


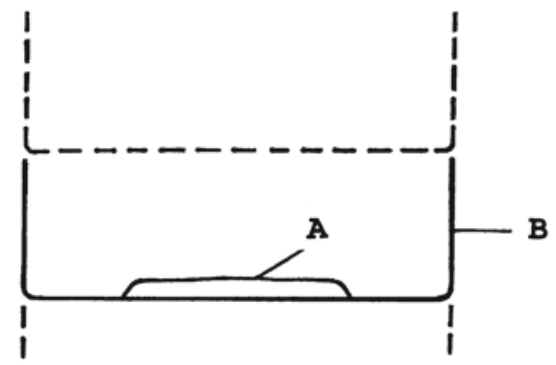

Figure 1. Schematical cross-section of the experimental design. A: Faecal sub-sample containing infective larvae of Dictyocaulus viviparus and with or without admixture of the nematode-trapping fungus Duddingtonia flagrans. B: Transparent tray.

of $D$. flagrans on D. viviparus, the following questions become pertinent:

1) Does the presence of Pilobolus spp. mycelium allow the nematode-trapping fungus $D$. flagrans to grow in cattle faeces?, and if it does, 2) can the nematode-trapping fungus subsequently be stimulated by the slow-moving $D$. viviparus $\mathrm{L}_{3}$-larvae to produce traps that can effectively control the cattle lungworm?

\section{Materials and methods}

\section{Experimental animals}

Two parasite-naive calves, housed in an experimental unit, were each infected (3 larvae per $\mathrm{kg}$ bodyweight) with a Danish strain of $D$. viviparus. After the end of the prepatent period fresh faeces containing lungworm larvae were sampled per rectum.

\section{Pilobolus fungi}

No particular measures were taken to ensure that the calves excreted Pilobolus spp. spores with their faeces, since it is known that calves fed on stable usually excrete Pilobolus spores more or less constantly all year round, because their food (hay, straw etc.) naturally contains spores (Grønvold \& Jørgensen 1985).

\section{Nematode-destroying fungi}

From a culture of D. flagrans (strain CI3), thick-walled chlamydospores (chl) were harvested in tap water. The chlamydospore-suspension was adjusted to approximately $10^{6}$ $\mathrm{chl} / \mathrm{ml}$.

\section{Experimental design}

The present study included 4 test series (I-IV) carried out from October to December 1995. The following design was used for all series: From a thoroughly mixed batch of fresh faeces containing lungworm larvae, 6 sub-samples of $200 \mathrm{~g}$ were made. Ten $\mathrm{ml}$ chlamydospore-suspension were mixed into each of 3 (experimental) faecal sub-samples, resulting in a fungal concentration of approximately 50,000 $\mathrm{chl} / \mathrm{g}$. The 3 other (control) faecal sub-samples received $10 \mathrm{ml}$ of tap water. Each faecal subsample was placed in individual semi-transparent polystyrene trays $(38 \times 28 \times 12 \mathrm{~cm})$ and formed as a small cow pat (diam.: $20 \mathrm{~cm}$; height: 1 $\mathrm{cm}$ ) with a smooth surface (Fig. 1).

The trays were stacked randomly and the upper tray was supplied with a lid. The set-up was placed in a room with a window, which allowed daylight to hit the faecal sub-samples. Light is necessary for Pilobolus to produce fruit bodies and therefore this arrangement allowed us to register if Pilobolus was present in the faeces. The room temperature was approximately $20^{\circ} \mathrm{C}$ and the incubation period was 8 days. Daily each cow pat was gently sprayed with tap water leaving a thin film of moisture on the faecal surface.

At the end of the incubation period, the surface of each pat and the inside of each tray were rinsed off gently with approximately $50 \mathrm{ml}$ of tap water. The water from each sample was poured into a test tube. Following centrifugation for 10 $\mathrm{min}$ at $1500 \mathrm{rpm}$, the supernatant was discarded, leaving a remnant of $10 \mathrm{ml}$. From each remnant 2 sub-samples of $0.5 \mathrm{ml}$ were transfer- 
Table 1. The number of infective Dictyocaulus viviparus larvae released from cow pats with $(+)$ and without $(-)$ admixture of the nematode-trapping fungus Duddingtonia flagrans, in each of the 4 series (I-IV) of experiments.

\begin{tabular}{|c|c|c|c|c|}
\hline \multirow{2}{*}{ Series } & \multicolumn{2}{|c|}{ Fungal material } & \multirow{2}{*}{$\begin{array}{l}\text { Reduction } \\
\text { (\%) }\end{array}$} & \multirow{2}{*}{ Statistics } \\
\hline & + & - & & \\
\hline I & $\begin{array}{r}65 \\
105 \\
95\end{array}$ & $\begin{array}{r}494 \\
1160 \\
286\end{array}$ & & \\
\hline Mean of serie I & 88 & 647 & 86 & $*$ \\
\hline II & $\begin{array}{r}799 \\
1520 \\
720\end{array}$ & $\begin{array}{l}3150 \\
1743 \\
5256\end{array}$ & & \\
\hline Mean of serie II & 1013 & 3383 & 70 & $*$ \\
\hline III & $\begin{array}{r}138 \\
54 \\
90\end{array}$ & $\begin{array}{l}3360 \\
4758 \\
5454\end{array}$ & & \\
\hline Mean of serie III & 94 & 4524 & 98 & $*$ \\
\hline IV & $\begin{array}{l}216 \\
320 \\
360\end{array}$ & $\begin{array}{l}2247 \\
1950 \\
3712\end{array}$ & & \\
\hline Mean of serie IV & 299 & 2636 & 89 & $*$ \\
\hline Total mean & & & $86 \%$ & \\
\hline
\end{tabular}

Asteriks indicate significant differences in larval count between the 2 groups of cow pats using a the Mann-Whitney U-test. ${ }^{*}: \mathrm{p}<0.05 ;{ }^{* *}: \mathrm{p}<0.01 ;{ }^{* * *}: \mathrm{p}<0.001$.

red to slides for counting $D$. viviparus larvae. Subsequently, the total number of infective lungworm larvae, released from each cow pat in 8 days, was calculated.

\section{Statistics}

Statistical analyses were made by the MannWhitney U-test (Siegel 1956). The level of significance was $5 \%$.

\section{Results}

Table 1 shows that larval counts from the experimental cow pats, which had received chlamydospores of $D$. flagrans, were significantly lower than counts from the control cow pats in particular in series I, III and IV. On average, the addition of the nematode-trapping fungus resulted in a $86 \%$ (range: $70 \%-98 \%$ ) reduced release of infective lungworm larvae from the faeces.

Pilobolus spp. fungi were observed in all trays, but no quantification was attempted.

\section{Discussion}

This paper shows that there was a significant reduction in the number of infective lungworm larvae (D. viviparus) released from the cow pats containing the nematode-trapping fungus $(D$. 
flagrans). On the average, a nematode-trapping efficacy of $86 \%$ was observed. In previous experiments, on gastrointestinal trichostrongyles, similar high reductions in Ostertagia and Cooperia larval numbers were reached as a result of feeding calves with $200 \times 10^{6}$ chlamydospores per animal per day (Nansen et al. 1995).

As Pilobolus spp. fungi were observed in all series, the present results indicate that Pilobolus fungi and $D$. flagrans can coexist in cattle faeces. Moreover, the results indicate that $D$. viviparus larvae can induce trap-production in $D$. flagrans in cattle faeces, as no other nematodes were observed in the faeces. However, future experiments will have to clarify whether the present results were caused mainly by: 1) reduced release of lungworm larvae caused by reduced Pilobolus growth in competition with the nematode-trapping fungus, or by 2) the nematode trapping activity of the latter alone.

If the present laboratory observations reflect the field situation reasonably, which is not necessarily the case, dosing of grazing calves with D. flagrans chlamydospores might reduce the herbage contamination, perhabs to a level that will prevent clinical manifestations of lungworm infection. According to Jørgensen (1981) strategic anthelmintic treatment of calves 6 and 8 weeks after turn-out onto contaminated pasture, was effective in controlling $D$. viviparus. Thus, given the efficacy of nematode destroying fungi as described above, dosing with fungi during the initial 2 months of the grazing season may be sufficient for practical control of bovine dictyocaulosis.

\section{Acknowledgement}

The authors highly appreciate the technical assistance of Leif Eiersted, and the financial support of Danish National Research Foundation and Chr. Hansen's Bio Systems.

\section{References}

Cooke RC: Two nematode-trapping Hyphomycetes, Duddingtonia flagrans gen.et comb.nov. and $\mathrm{Mo}$ nacrosporium mutabilis sp. nov. Transactions of the British Mycological Society. 1969, 53, 315319.

Grønvold J, Jørgensen RJ: PILOBOLUS Tode 1784. Danmarks Veterinær- og Jordbrugsbibliotek, Copenhagen. 1985, 124 pp.

Grønvold J, Wolstrup J, Larsen M, Henriksen SA, Nansen P: Biological control of Ostertagia ostertagi by feeding selected nematode-trapping fungi to calves. J. Helminthol. 1993, 67, 31-36.

Jørgensen RJ: Studies on the lungworm Dictyocaulus viviparus (Bloch, 1782) and its epidemiology in young cattle with a description of an attempt to prevent parasitic bronchitis. Thesis. Danmarks Veterinær- og Jordbrugsbibliotek, Copenhagen. $1981,77 \mathrm{pp}$.

Jørgensen RJ, Rønne H, Helsted C, Iskander AR: Spread of infective Dictyocaulus viviparus larvae in pasture and to grazing cattle: Experimental evidence of the role of Pilobolus fungi. Vet. Parasitol. 1982, 10, 331-339.

Larsen M, Nansen P, Wolstrup J, Grønvold J, Henriksen SA, Zorn A: Biological control of trichostrongyles in calves by the fungus Duddingtonia flagrans fed to animals under natural grazing conditions. Vet. Parasitol. 1995, 60, 321-330.

Larsen M, Nansen P, Grøndahl C, Thamsborg SM, Grønvold J, Wolstrup J, Henriksen SA, Monrad J: The capacity of the fungus Duddingtonia flagrans to prevent strongyle infections in foals on pasture. Parasitology. 1996, 113, 1-6.

Nansen P, Grønvold J, Henriksen SAa, Wolstrup J.: Interactions between the predacious fungus $\mathrm{Art}$ hrobotrys oligospora and third-stage larvae of a series of animal-parasitic nematodes. Vet. Parasitol. 1988, 26, 329-337.

Nansen P, Larsen M, Grønvold J, Wolstrup J, Zorn A, Henriksen SAa: Prevention of clinical trichostrongylidosis in calves by strategic feeding with the predacious fungus Duddingtonia flagrans. Parasitol. Res. 1995, 81, 371-374.

Nansen P, Larsen M, Roepstorff A, Grønvold J, Wolstrup J, Henriksen SAa: Control of Oesophagostomum dentatum and Hyostrongylus rubidus in outdoor-reared pigs through daily feeding with the microfungus Duddingtonia flagrans. (sent to Parasitol. Res.). 
Siegel S: Non-parametric statistics for the behavioral sciences. McGraw-Hill, Kogakusha, Tokyo, 1956, $312 \mathrm{pp}$.

Wolstrup J, Grønvold J, Henriksen SA, Nansen P, Larsen $M$, Bøgh $H O$, Ilsøe B: An attempt to implement the nematode-trapping fungus Duddingtonia flagrans in biological control of first year grazing calves. Journal of Helminthology. 1994, $68,175-180$.

\begin{abstract}
Sammendrag
Biologisk kontrol af Dictyocaulus viviparus ved hjaelp af rovsvampe.

Larver af kvægets lungeorm, Dictyocaulus viviparus, blev dyrket i enheder af $200 \mathrm{~g}$ kvæggødning placeret i semi-transparente kasser i laboratoriet. I hver af 4 eksperimentelle serier, hvor ovennævinte opstilling blev anvendt, blev chlamydosporer (chl) af den nematode-fangende svamp Duddingtonia flagrans tilblandet halvdelen af opstillingerne $\mathrm{i}$ en koncentration på $50.000 \mathrm{chl} / \mathrm{g}$. I alle 4 serier var der en signifikant reduktion i spredningen af infektive lungeormlarver fra kulturer tilblandet chlamydosporer. Den gennemsnitlige reduktion i spredningen, forårsaget af chlamydosporer, var $86 \%$.
\end{abstract}

(Received December 4, 1996; accepted February 27, 1997).

Reprints may be obtained from: Sv. Aa. Henriksen, The Danish Veterinary Laboratory, Bülowsvej 27, DK-1790 Copenhagen V, Denmark. E-mail: saah@svs.dk, tel: +45353002 11, fax: +4530 0120. 
